\title{
Pengaruh Merokok terhadap Kadar Trombosit Mahasiswa Universitas Sam Ratulangi
}

\author{
${ }^{1}$ Expecially K. Assa \\ ${ }^{2}$ Joice N. A. Engka \\ ${ }^{2}$ Sylvia R. Marunduh
}
${ }^{1}$ Program Studi Pendidikan Dokter Fakultas Kedokteran Universitas Sam Ratulangi Manado
${ }^{2}$ Bagian Fisiologi Fakultas Kedokteran Universitas Sam Ratulangi Manado
Email: assaexpecially@gmail.com

\begin{abstract}
Smoking causes various diseases as well as disabilities and endangers almost every organ of the human body. The effect of smoking on the body is inter alia systemic inflammatory response, namely through stimulation of the hematopoietic system (mainly occurs in the bone marrow), resulting in increased production of erythrocytes and leukocytes and decreased MCV and platelets. Smoking affects platelets that causes an increase in the occurence of atherosclerosis and its risk factors due to the increase in the mean platelet volume (MPV). This study was aimed to determine the effect of smoking on platelet levels among students of Sam Ratulangi University. This was a retrospective study. Data were analyzed by using the Pearson product moment test. Subjects were 51 male students of the Faculty of Engineering, Sam Ratulangi University. The results showed that 48 subjects (94.1\%) had normal platelet levels and only three students (5.9\%) had high platelet levels; no subjects had low platelet level. The Pearson product moment test obtained $P$ values of 0.985 and 0.104 for the effect of smoking (duration of smoking and number of cigarettes per day) on the platelet levels of the students. Conclusion: There was no significant effect of smoking on platelet levels.
\end{abstract}

Keywords: smoking, platelet level

\begin{abstract}
Abstrak: Merokok menyebabkan penyakit dan kecacatan serta membahayakan hampir setiap organ tubuh manusia. Efek merokok pada tubuh berupa terjadinya respon inflamasi sistemik yaitu melalui stimulasi sistem hematopoietik yang terutama terjadi dalam sumsum tulang, berupa peningkatan produksi eritrosit dan leukosit serta penurunan MCV dan trombosit. Pengaruh rokok terhadap trombosit ialah terjadinya peningkatan aterosklerosis serta faktor risiko terjadinya penyakit ateroklerosis yang diakibatkan oleh peningkatan mean platelet volume (MPV). Penelitian ini bertujuan untuk mengetahui pengaruh merokok terhadap kadar trombosit mahasiswa Universitas Sam Ratulangi. Jenis penelitian ialah retrospektif. Uji statistik menggunakan Pearson Product Moment. Terdapat 51 mahasiswa laki-laki dari Fakultas Teknik Universitas Sam Ratulangi sebagai subyek penelitian. Hasil penelitian mendapatkan subyek terbanyak memiliki kadar trombosit normal yaitu 48 mahasiswa $(94,1 \%)$ dan hanya tiga mahasiswa $(5,9 \%)$ dengan kadar trombosit tinggi; tidak terdapat subyek dengan kadar trombosit rendah. Hasil uji Pearson Product Moment pengaruh merokok (lama merokok dan jumlah rokok harian) terhadap kadar trombosit mahasiswa mendapatkan nilai $P=0,985$ dan $P=0,104$. Simpulan: Tidak terdapat pengaruh bermakna dari merokok terhadap kadar trombosit.
\end{abstract}

Kata kunci: merokok, kadar trombosit 
Merokok dapat menyebabkan penyakit dan kecacatan serta membahayakan hampir setiap organ tubuh manusia. Menurut Centers for Disease Control and Prevention (CDC), untuk setiap orang yang meninggal karena merokok, setidaknya terdapat 30 orang yang hidup dengan penyakit serius yang berkaitan dengan merokok. ${ }^{1}$ Data dari World Health Organization (WHO) juga menunjukkan bahwa lebih dari 7 juta orang meninggal setiap tahunnya karena rokok. Dari angka tersebut sekitar 6 juta orang meninggal ialah perokok aktif dan sekitar 890 ribu orang yang meninggal ialah perokok pasif. ${ }^{2}$

Merokok telah menjadi bagian dari gaya hidup masyarakat. Data Riskesdas tahun 2018 menunjukkan bahwa jumlah perokok yang berusia di atas 15 tahun sebanyak 33,8\%. Dari jumlah tersebut $62,9 \%$ merupakan perokok laki-laki dan $4,8 \%$ merupakan perokok perempuan. ${ }^{3}$ Kebiasaan merokok ini akan mengakibatkan peningkatan risiko terkena berbagai penyakit, dan banyak diantaranya berakibat fatal. Sebagian besar kematian yang diakibatkan oleh merokok ialah penyakit kanker, penyakit pernapasan, dan penyakit kardiovaskular. Merokok juga merupakan faktor risiko untuk stroke, kebutaan, ketulian, sakit punggung, osteoporosis, dan penyakit pembuluh darah perifer. ${ }^{4}$ Berdasarkan data WHO, di Indonesia penyakit yang sering mengakibatkan kematian akibat merokok ialah penyakit kardiovaskular yaitu penyakit jantung dan stroke. ${ }^{5}$

Asap rokok mengandung lebih dari 4000 senyawa yang memiliki dampak merugikan bagi kesehatan manusia, di antaranya yaitu radikal bebas, nikotin, dan karbon monoksida yang dianggap paling bertanggung jawab atas efek farmakologi. ${ }^{6}$ Efek merokok pada tubuh mengakibatkan terjadinya respon inflamasi sistemik yaitu melalui stimulasi sistem hematopoietik terutama terjadi pada sumsum tulang, dimana terjadi peningkatan produksi eritrosit dan leukosit serta penurunan $\mathrm{MCV}$ dan trombosit. ${ }^{7}$

Trombosit merupakan fragmen sitoplasma megakariosit yang tidak berinti dan terbentuk di sumsum tulang. Trombosit berfungsi dalam hemostasis yaitu menghentikan perdarahan dan memperbaiki pembuluh darah yang cedera. ${ }^{8}$ Trombosit memiliki peran penting dalam patofisiologi penyakit kardiovaskular yang dimediasi oleh pembentukan trombus yang patologik.9 Aktivasi trombosit dan trombosis pada lokasi plak ateromatosa memainkan peran yang penting dalam patofisiologi kejadian koroner akut. ${ }^{10,11}$

Rokok merupakan salah satu faktor risiko terjadinya penyakit kardiovaskular. Pengaruh rokok terhadap trombosit menyebabkan terjadinya peningkatan aterosklerosis serta faktor risiko terjadinya penyakit aterosklerotik yang diakibatkan karena terjadi peningkatan mean platelet volume (MPV). ${ }^{12,13}$

Hasil penelitian yang dilakukan oleh Pematasari menunjukkan bahwa jumlah trombosit pada perokok lebih tinggi dibandingkan dengan yang bukan perokok walaupun keduanya masih termasuk dalam kategori trombosit normal. ${ }^{14}$ Penelitian yang dilakukan oleh Habibah ${ }^{15}$ mendapatkan bahwa kategori trombosit normal terdapat pada sebagian perokok aktif sedangkan pada perokok pasif memiliki kategori trombosit yang tinggi karena hasil yang diperoleh lebih dari normal. ${ }^{15}$

Penelitian ini bertujuan untuk mengetahui pengaruh merokok terhadap kadar trombosit mahasiswa Universitas Sam Ratulangi.

\section{METODE PENELITIAN}

Penelitian ini merupakan studi retrospektif. Data penelitian merupakan data sekunder yang diambil dari bank data di Bagian Fisiologi Fakultas Kedokteran Universitas Sam Ratulangi Manado tahun 2018. Sampel penelitian menggunakan cara purposive sampling yang diambil dari mahasiswa Fakultas Teknik yang memenuhi kriteria inklusi yaitu sebanyak 51 orang.

\section{HASIL PENELITIAN}

Berdasarkan data sekunder yang diambil di Bagian Fisiologi Fakultas 
Kedokteran Universitas Sam Ratulangi Manado tahun 2018 didapatkan sampel sebanyak 51 mahasiswa dengan jenis kelamin laki-laki dari Fakultas Teknik.

Data yang telah dikumpulkan terbagi atas beberapa variabel yang kemudian disusun dan disajikan dalam tabel. Tabel 1 memperlihatkan bahwa subyek penelitian terbanyak berusia 21 tahun yaitu 19 mahasiswa $(37,3 \%)$ diikuti dengan usia 20 tahun yaitu 12 mahasiswa $(23,5 \%)$. Subjek dengan usia 17 tahun dan 23 tahun merupakan usia termuda dan tertua yang mengikuti penelitian ini dengan jumlah masing-masing 2 mahasiswa (3,9\%).

Tabel 1. Karakteristik subyek penelitian berdasarkan usia

\begin{tabular}{ccc}
\hline $\begin{array}{c}\text { Usia } \\
\text { (tahun) }\end{array}$ & $\mathbf{n}$ & \% \\
\hline 17 & 2 & 3,9 \\
18 & 3 & 5,9 \\
19 & 9 & 17,6 \\
20 & 12 & 23,5 \\
21 & 19 & 37,3 \\
22 & 4 & 7,8 \\
23 & 2 & 3,9 \\
Total & 51 & 100 \\
\hline
\end{tabular}

Tabel 2 menyajikan parameter lama merokok terbanyak ialah selama 1-5 tahun berjumlah 38 mahasiswa $(74,5 \%)$ sedangkan subyek dengan jumlah rokok harian terbanyak ialah yang merokok sebanyak 110 batang per hari dengan jumlah 29 mahasiswa $(56,9 \%)$.

Tabel 2. Karakteristik subyek penelitian berdasarkan penggunaan rokok

\begin{tabular}{lcc}
\hline \multicolumn{1}{c}{ Parameter } & n & \% \\
\hline Lamanya merokok & & \\
1-5 tahun & 38 & 74,5 \\
6-10 tahun & 13 & 25,5 \\
Jumlah rokok harian & & \\
1-10 batang & 29 & 56,9 \\
11-20 batang & 22 & 43,1 \\
\hline
\end{tabular}

Tabel 3 menampilkan bahwa kategori perokok terbanyak ialah kategori perokok ringan sejumlah 29 mahasiswa $(56,9 \%)$ sedangkan perokok sedang sejumlah 22 mahasiswa $(43,1 \%)$. Tidak terdapat subyek dengan kategori perokok berat.

Tabel 3. Karakteristik subyek penelitian berdasarkan kategori perokok menurut WHO

\begin{tabular}{lcc}
\hline $\begin{array}{c}\text { Kategori } \\
\text { perokok }\end{array}$ & n & $\%$ \\
\hline Ringan & 29 & 56,9 \\
Sedang & 22 & 43,1 \\
Berat & 0 & 0 \\
Total & 51 & 100 \\
\hline
\end{tabular}

Tabel 4 memperlihatkan subyek dengan kadar trombosit normal sebanyak 48 mahasiswa $(94,1 \%)$ sedangkan kadar trombosit tinggi hanya sebanyak 3 mahasiswa $(5,9 \%)$ dan tidak terdapat responden dengan kadar trombosit rendah.

Tabel 4. Karakteristik subyek penelitian berdasarkan kadar trombosit

\begin{tabular}{lccc}
\hline $\begin{array}{c}\text { Klasifikasi } \\
\text { kadar } \\
\text { trombosit }\end{array}$ & $\begin{array}{c}\text { Nilai } \\
\text { rujukan } \\
\left(\mathbf{1 0}^{\mathbf{3}} / \mathbf{m m}^{\mathbf{3}}\right)\end{array}$ & n & \% \\
\hline Rendah & $<150$ & 0 & 0 \\
Normal & $150-450$ & 48 & 94,1 \\
Tinggi & $>450$ & 3 & 5,9 \\
\hline
\end{tabular}

Dalam penelitian ini digunakan uji statistik Pearson Product Moment karena pada uji normalitas diperoleh sebaran data normal. Tabel 5 menunjukkan bahwa nilai sig $P>0,05$ yang berarti tidak memiliki korelasi sehingga dapat diasumsikan bahwa variabel merokok (lama merokok dan jumlah rokok harian) tidak memiliki pengaruh terhadap variabel kadar trombosit.

Tabel 5. Uji Pearson Product Moment terhadap lama merokok dan jumlah rokok harian

\begin{tabular}{lcc}
\hline \multicolumn{1}{c}{ Trombosit } & $\begin{array}{c}\text { Lama } \\
\text { merokok }\end{array}$ & $\begin{array}{c}\text { Jumlah } \\
\text { rokok } \\
\text { harian }\end{array}$ \\
\hline Pearson Correlation &, 003 &, 230 \\
Sig. (2-tailed) &, 985 &, 104 \\
$\mathrm{~N}$ & 51 & 51 \\
\hline
\end{tabular}

\section{BAHASAN}

Berdasarkan hasil penelitian yang telah dilakukan terhadap mahasiswa Fakultas 
Teknik Universitas Sam Ratulangi pada bulan Oktober-November 2018 didapatkan bahwa tidak terdapat pengaruh bermakna antara merokok dengan kadar trombosit. Hasil penelitian ini didukung oleh penelitian yang dilakukan oleh Misra dan Venkatesh ${ }^{15}$ yang menunjukkan bahwa tidak terdapat perbedaan bermakna antara merokok terhadap kadar trombosit pada perokok dan nonperokok. Misra dan Venkatesh ${ }^{15}$ mengemukakan bahwa hal ini dikarenakan oleh faktor usia, dengan usia responden penelitian yang diambil masih termasuk dalam kategori yang masih muda. Pada penelitian ini, subyek penelitian juga termasuk dalam kategori usia muda.

Pada penelitian ini juga didapatkan bahwa subyek yang megikuti penelitian termasuk dalam kategori perokok ringan dan sedang. Tidak terdapat subyek dengan kategori perokok berat. Hal ini dapat menjadi salah satu penyebab merokok tidak berpengaruh bermakna terhadap kadar trombosit. ${ }^{16}$ Hal ini juga didukung oleh penelitian yang dilakukan oleh Sherke et al 17 yang mengemukakan bahwa pada perokok yang merokok >20 batang sehari atau berdasarkan WHO termasuk dalam kategori perokok berat akan terjadi peningkatan kadar trombosit yang signifikan. Pada penelitian ini, tidak terdapat subyek yang merokok $>20$ batang sehari atau yang termasuk dalam kategori perokok berat.

Penelitian mengenai pengaruh merokok terhadap kadar trombosit masih kontroversial. Penelitian serupa telah dilakukan oleh Suwansaksri et al yang menunjukkan bahwa tidak terdapat perbedaan bermakna antara merokok dan kadar trombosit pada perokok dan non-perokok. ${ }^{17}$ Penelitian Sherke et al ${ }^{17}$ dan Butkiewicz et $\mathrm{al}^{18}$ juga menunjukkan bahwa tidak terdapat perbedaan bermakna dari parameter trombosit pada perokok dan nonperokok laki-laki. Penelitian yang lain juga menunjukkan bahwa pengaruh merokok terhadap kadar trombosit yang dilakukan pada perokok akut yang merokok sebanyak 2 batang berturut-turut akan mengaktifkan leukosit dan merusak endotel tetapi tidak memengaruhi aktivitas trombosit. ${ }^{19}$
Berdasarkan hasil penelitian, didapatkan bahwa sebagian besar subyek memiliki kadar trombosit normal yaitu sebanyak 48 mahasiswa $(94,1 \%)$. Hasil penelitian ini selaras dengan yang dikemukakan oleh Habibah $^{15}$ yang menunjukkan bahwa sebagian besar perokok aktif memiliki kategori trombosit normal. Penelitian lain yang dilakukan oleh Sundari et $\mathrm{al}^{20}$ menunjukkan hasil yang mirip yaitu bahwa sebagian besar laki-laki perokok aktif memiliki jumlah trombosit normal.

Pada penelitian ini, subyek yang memiliki trombosit tinggi berjumlah 3 mahasiswa $(5,9 \%)$. Trombositosis merupakan istilah yang digunakan untuk kadar trombosit yang melebihi batas normal; hal ini berhubungan dengan peningkatan risiko dari trombosis. $^{21}$

Trombosit pada perokok memiliki tingkat sensitivitas yang kurang terhadap prostasiklin eksogen sehingga hal ini memengaruhi usia dan fungsi trombosit. Kandungan zat kimia yang terdapat pada rokok yang masuk ke dalam tubuh akan merangsang tromboksan A2 dalam darah yang berperan untuk mengaktifkan trombosit baru serta meningkatkan agregasi trombosit. Agregasi trombosit dapat kembali normal bila terdapat prostasiklin di dalam darah yang berperan untuk menghambat agregasi trombosit serta menjaganya agar tetap stabil. ${ }^{22}$

Terdapat beberapa hal yang dapat menimbulkan perbedaan hasil penelitian yaitu seperti faktor genetik, jenis kelamin, umur, dan iklim yang diketahui berperan terhadap trombosit. ${ }^{23}$ Studi meta analisis yang dilakukan oleh Soranzo et $\mathrm{al}^{24}$ mendapatkan bahwa terdapat 12 lokus yang dihasilkan berhubungan dengan mean platelet volume pada 13,943 sampel dari enam populasi orang Eropa. Penelitian yang dilakukan oleh Biino et $\mathrm{al}^{25}$ mendapatkan bahwa kadar trombosit pada perempuan lebih tinggi daripada laki-laki; hal ini disebabkan karena perbedaan dari profil hormon, dimana diketahui bahwa megakariosit dan trombosit mengekspresikan reseptor hormon steroid. ${ }^{26}$ Berkurangnya sel induk hematopoietik pada 
individu yang menua dapat berhubungan dengan kadar trombosit. ${ }^{27}$ Berdasarkan penelitian longitudinal, faktor iklim memiliki peran sebesar $2 \%$ terhadap kadar trombosit serta menyebabkan peningkatan jumlah trombosit pada musim gugur dan musim dingin. ${ }^{28}$

\section{SIMPULAN}

Berdasarkan hasil penelitian ini maka disimpulkan bahwa tidak terdapat pengaruh merokok terhadap kadar trombosit pada mahasiswa Universitas Sam Ratulangi.

\section{SARAN}

Disarankan untuk meneliti faktor kebiasaan hidup dalam hal pengaruhnya terhadap kadar trombosit pada perokok.

Perlu diteliti lebih lanjut mengenai parameter lain dari merokok, yaitu banyaknya merokok untuk kategori perokok berat dan kebiasaan merokok.

Juga diperlukan penelitian lanjut mengenai karakteristik trombosit pada perokok (mean platelet volume/MPV, platelet distribution width/PDW, platelet crit/PCT, dan platelet large cell ratiol PLCR) .

\section{DAFTAR PUSTAKA}

1. Centers for Disease Control and Prevention. Smoking \& Tobacco Use: Basic Information. 2018. [cited 2019 March 12]. Available from: https://www.cdc. gov/tobacco/basic_information/health_ effects/index.htm

2. World Health Organization. Tobacco. 9 March 2018. [cited 2019 March 12]. Available from: https://www.who.int/news-room/ fact-sheets/detail/tobacco

3. Badan Penelitian dan Pengembangan Kesehatan Kementerian Kesehatan RI. Hasil Utama RISKESDAS 2018. Januari 2019. [cited 2019 March 12]. Available from: http://www.depkes.go.id/ resources/download/info-terkini/hasilriskesdas-2018.pdf

4. West R. Tobacco smoking: Health impact, prevalence, correlates and inter ventions. Psychology \& Health. 2017; 32(8):1018-36.

5. World Health Organization. Indonesia Tobacco Factsheet 2018. [cited 2019 March 12].
Available from: https://apps.who.int/ iris/bitstream/handle/10665/272673/wn td_2018_indonesia_fs.pdf?sequence $=1$

6. Malenica M, Prnjavorac B, Bego T, Dujic T, Semiz S, Skrbo S, et al. Effect of cigarette smoking on haematological parameters in healthy population. Med Arch. 2017;71(2):132-6.

7. Purnamasari E. Pengaruh merokok pada viskositas darah. PharmaMedika. 2018;10(1)47-56.

8. Sloane E. Anatomy and Psysiology: An Easy Learner (1st ed). England: Jones \& Bartlett Publishers; 1994.

9. Nocella C, Biondi-Zoccai G, Sciarretta S, Peruzzi M, Pagano F, Loffredo L, et al. Impact of tobacco versus electronic cigarette smoking on platelet function. Am J Cardiol. 2018; 122(9):1477-81.

10. DiGiacomo SI, Jazayeri MA, Barua RS, Ambrose JA. Environmental tobacco smoke and cardiovascular disease. Int $\mathbf{J}$ Environ Res Public Health. 2018; 16(1):e96.

11. Barua RS, Ambrose JA. Mechanism of coronary thrombosis in cigarette smoke exposure. Ateroscler Thromb Vasc Biol. 2013;33(7):1460-7.

12. Padmavathi P, Reddy V, Maturu P, Varadacharyulu N. Smoking-induced alterations in platelet membrane fluidity and $\mathrm{Na}(+) \mathrm{K}(+)$-ATPase activity in chronic cigarette smokers. J Atheroscler Thromb. 2010;17(6):619-27.

13. Yarliogllues M, Ardic I, Dogdu O, Akpek M, Zencir C, Kasapkara HA, et al. The acute effects of passive smoking on mean platelet volume in healthy volunteers. Angiology. 2012;63(5): 353-7.

14. Permatasari TO. Pengaruh rokok terhadap jumlah trombosit pada relawan laki-laki di Kota Cirebon. Tunas Medika Jurnal. 2015;2(5).

15. Habibah, Salyekti S, Endang Y. Gambaran jumlah trombosit pada perokok aktif dan pasif. STIKES Insan Cendekia Medika, 2018.

16. Misra J, Venkatesh $K$. Comparison of platelet count in smokers versus nonsmokers. J Evid Based Med Health. 2018;5(19):1522-28.

17. Sherke BA, Vadapalli K, Bhargava DV, Sherke AR, Gopireddy MMR. Effects of number of cigarettes smoked 
per day on red blood cell, lecocyte and platelet count in adult Indian male smokers - a case control study. IJMRHS. 2016;5(2):13-7.

18. Butkiewicz AM, Kemona-Chętnik I, Dymicka-Piekarska V, MatowickaKarna J, Kemona H, Radziwon P. Does smoking affect thrombocytopoiesis and platelet activation in woman and men? Adv Med Sci. 2006;51:123-26.

19. Blann AD, Kirkpatrick U, Devine C, Naser S, McCollum CN. Influence of acute smoking on leucocytes, platelets and endothelium, Atherosclerosis. 1998; 141(1):133-139.

20. Sundari R, Widjaya DS, Nugraha A. Lama merokok dan jumlah konsumsi rokok terhadap trombosit pada laki-laki perokok aktif. Kesmas: National Public Health Journal. 2015;9(3):257-63.

21. Skoda RC. Thrombocytosis. Hematology Am Soc Hematol Educ Program. 2009;159-67.

22. Hioki Y, Aoki N, Kawano K, Homori M, Hasumura $Y$, Yasumura $T$, et al. Acute effects of cigarette smoking on platelet-dependent thrombin generation. Eur Heart J. 2001;22:56-61.

23. Daly ME. Determinants of platelet count in humans. Haemotologica. 2011;95(1): 10-3.
24. Soranzo N, Spector TD, Mangino $M$, Kühnel B, Rendon A,Teumer A, et al. A genome-wide meta-analysis identified 22 loci associated with eight haematological parameters in the HaemGen consortium. Nat Genet. 2009;41(11):1182-90.

25. Biino G, Balduini C, Casula L, Cavallo P, Vaccargiu S, Parracciani D, et al. Analysis of 12,517 inhabitants of a Sardinian geographic isolate reveals that predispositions to thrombocytopenia and thrombocytosis are inherted traits. Haematologica. 2011; 96(1):96-101.

26. Khetawat G, Faraday N, Nealen ML, Vijayan KV, Bolton E, Noga SJ, et al. Human megakaryocytes and platelets contain the estrogen receptor beta and androgen receptor (AR): testosterone regulates AR expression. Blood. 2000;95(7)2289-96.

27. Segal JB, Moliterno AR. Platelet counts differ by sex, ethnicity, and age in the United States. Ann Epidemiol. 2006; 16(2):123-30.

28. Buckley MF, James JW, Brown DE, Whyte GS, Dean MG, Chesterman CN, et al. A novel approach to the assessment of variations in the human platelet count. Thromb Haemost. 2000;83(3):480-4. 